\title{
From Postfiction to Protofiction: \\ Conspiracy Theory, Social Networks and Confabulation
}

\author{
Toby Bennett
}

\begin{abstract}
IN THE FIRST ISSUE OF DANDELION, Gill Partington's exegesis of Christian postapocalyptic novel series Left Behind leads her to posit the emergence of a 'postfictional' mode of writing, the 'networked genre', arguing that it is in fringe arenas where the most radical transformations of traditional modes of novelistic engagement are likely to be found. By calling upon their belief in the imminence of the prophesied moment of Rapture, the series engages its readers' profound personal investment in their faith, forming a rehearsal of sorts for their own impending narrative pathways. Her claim is thus that the books 'represent a reality, but one which has yet to take place'. Online interactions on websites, forums and social networks, as well as immersion in the spin-off computer games, both anticipate and extend the series, and are requisite components of its postfictional status. If we are to accept the Left Behind phenomena as paradigmatically postfictional, then this may be because, as Partington implies, these creative artefacts emerge from the convergence of two 'real-world' trajectories that already blur the boundaries between fact and fiction: systems of belief (specifically but not exclusively religious) and networked technology. Here I consider some of the implications of such a convergence, focusing on conspiracy theories and patterns of online
\end{abstract}


interaction. Ultimately, in the light of recent neuroscientific research, my suggestion is that these phenomena enable a 'protofictional' approach towards making sense of the world.

Faith traditionally has an uneasy relationship with politics, epitomised by the Western secular demand to segregate the state from religion. Attempting to reconcile faith with reason, Terry Eagleton notes the reappearance of religion in the public eye in recent times, from radical Islam to Christian fundamentalism, suggesting that any resurgence may be influenced by mass disillusionment with global politics. While many are scornful of conspiracy theorists, the rise in visibility of what Richard Hofstadter calls the 'paranoid style' in cultural production (from Pynchon and DeLillo to the X Files, the Zeitgeist series and Michael Moore) perhaps speaks to a similar political dissatisfaction. Conspiracy theories interpret the world in much the same way-as media distillations of global events typically offering 'image-centred, narrative-based accounts of strips of reality', that help to create, as Arjun Appadurai has it, 'protonarratives of possible lives, fantasies that could become prolegomena to the desire for acquisition and movement'. Unsurprisingly then, onto its end-times framework, Left Behind maps a clumsy but familiar articulation of fears over shadowy elites and the New World Order, subjecting the residents of the period of Tribulation to the despotic world government of the 'Global Community' and the 'Enigma Babylon One World Faith', a totalitarian religion headed by the Antichrist himself. Indeed, the Left Behind: Eternal Forces computer game opens with a biblical quotation that could conceivably have come from conspiracy theorist pin-up David Icke: 'For we are not fighting against flesh-and-blood enemies but against evil rulers and authorities of the unseen world, against mighty powers in this dark world and against evil spirits in heavenly places (Ephesians 6:12).' The novels' alignment of religious belief with socio-political suspicion demonstrates the ease with which pre-existing metaphysical narratives of sacred hopes and secular fears might synthesise.

Conspiracy theories, even in book form, ride the same razor-thin edge as Left Behind, consciously evoking literary tropes and structures in their quest to unveil a specific brand of Truth. This is especially true when considering those (abundant) aspects that overlap with 'new age' spiritualism: as its provocative title might suggest, Bob Frissell's Nothing In This Book Is True But It's Exactly How Things Are is something of a key text in this respect. Ostensibly a treatise on rebirthing and meditation as a path to achieving 'Christ-Consciousness', through which we can reach the higher spiritual dimensions where we will find our destiny, Frissell situates his claims within a formidably holistic narrative of conspiracy theory and Eastern-derived new age philosophies. As the introduction explains, the story that unfolds is:

one of many stories and also one of many versions of one of many stories. It is a story we are living, and it is a story we are changing to such a degree that it is becoming unrecognizable even as it is being absolutely and unambiguously revealed for what it is [... Thus] I leave it with readers to decide if this is all true or if none of it is true. Because in the end your own word must be enough. [...] In fact your word is the only thing that will get you through. 
Similarly, The Montauk Project, which 'uncovers' some of the United States government's experiments in time-travel and mind control over the course of the latter half of the twentieth century, advises its readers that the book is 'an exercise in consciousness' built on 'soft facts', which are 'not untrue, they are just not backed up by irrefutable documentation'; 'hard facts', we are told, 'have been very difficult to obtain', due to the nature of the subject matter. Consequently, 'the book is being presented as non-fiction as it contains no falsehoods to the best knowledge of the authors. However, it can also be read as pure science fiction if that is more suitable to the reader'. The religious tone and the manner of interpellating the reader into the narrative of Truth are echoed, interestingly enough, by the Church of Scientology (the religion that springs from the Science Fiction novels of its founder L. Ron Hubbard), which tells us on its website that 'no-one is asked to accept anything as belief or on faith. That which is true for you is what you have observed to be true'. The sceptic may find this kind of self-effacing magnanimity surprising in the face of the incredible revelations to be found in each of these three examples. We are unlikely to place our faith in anything which openly confesses an inability to prove its outrageous claims. Nonetheless, the approach appeals to reason by investing in our trust.

Conspiracy theory thus explicitly places us in the interpretative driving seat. When our own narrative guides all others, the baffling diversity of experience can be localised and moulded into a series of meaningful 'truths'. Our online experience is arranged in a similar manner and for this reason conspiracy theory has achieved symbiosis with the internet. Every problem can be explained by a suitable truth, or several, if one appeals to fictional devices to support this protofictional drive.

The rhizomatic sub-cultural plains of the internet allow the 'rehearsals' of the Left Behind series to gestate and propagate, such that the postfictional apogee that is the apocalyptic thriller exists, as Partington claims, 'in dialogue with the Internet'. In essence, postfictionality is unleashed by its dependency on fluid interpersonal exchange. Conventionally, the novel as a discrete, disconnected unit fosters the private intimacy we often associate with the reading experience. Put differently, fiction's ability to engage with the wider world is structurally unbounded by the very physicality that seems to draw us in. The networked reality of the internet that informs postfictional writing, on the other hand, consists of imagined communities of disparate participants threading multiple distinct experiences through each other, unobstructed by such inconveniences as time or space, cultural divides or ideological incompatibilities. Avid internet users will appreciate Caroline Bassett's argument that, even when hyperlinked to the entire history of human experience in an instantly accessible data pool of potentially infinite depth, narrative remains 'the central means through which humans interpret the world as they have grasped it through experience, stretching from fiction and history to lived experience'. It is precisely this narrative desire (a desire for narrative and a desire to be narrated) that one might deem expedient to term 'protofictional', in order to describe reality's asymptotic tendency towards literary forms. 'A life storied is a life made meaningful, and any life, however 
vapid, is at least storiable', writes John Sturrock, regarding autobiography, but seemingly anticipating the rise of this networked subject; 'whoever narrates his or her life is willing its transformation from a lived farrago into a thought whole.' The difference here is that the protofictional subject is not 'whole' but stratified into interlocking novelistic characters: it is not the autobiography of the individual that we write but that of what Deleuze called the dividualtechnologised society's reduction of the subject into detached and classifiable data streams.

Narratives, of course, require protagonists and the digital subject accordingly forms an essential component whereby, through constant preening, editing and updating of avatars, profile pages and statuses, one is able to administer the chaos of everyday life. We customise our likes and dislikes, label our political and religious viewpoints and compile our favourite music, books and movies using clickable tags that interface with other users' preferences; we are picked out in other people's photographs (or we fastidiously do it ourselves); we join groups that display our solidarity with the arcane causes we didn't know we wanted to champion (whether it is the release of a distant political prisoner or a penchant for long-lost childhood desserts); we update our location in real-time. The compulsion to assemble, categorise and digitise our personality traits is attractive enough for the amateur bureaucrats amongst us but the real fascination of social networks lies in the ability to connect our personal archives with others', teasing out commonalities and asserting individualities. In doing so we are dimly aware that we are engaged in writing the autobiography of what Andrew Bucksbarg terms our 'default other'-even if this hefty volume is read only (if in keen detail) by advertisers. It is the protofictional experience of online social networking that prompts Facebook's EMEA Vice President Joanna Shields to declare that "the most important word in the internet today is not "search" any more but it's "share". Searching, she argues, is merely functional, whereas sharing is transactional: 'when we share something we're at the beginning of the story and the beginning of a conversation.' The recourse to the metaphor of the story may sound like glib marketing rhetoric but it nonetheless betrays a hypermodern susceptibility to literary allure, the 'always possible truth' that Gadamer claimed 'is what emerges from detaching what is spoken from the speaker and from the permanence that writing bestows'. Here, as in conspiracy theory, fictionality assumes a gravitas that anchors real-life experience.

In his treatise on the art of the novel, Milan Kundera discusses how the Russian army's arrival in Czechoslovakia in 1968 prompted him to recall the Czech nationalist revival that emerged in the nineteenth century in reaction against Bohemia's increasing Germanisation. In order to fully empathise, Kundera claims that, rather than a clear understanding of historical events, he needed:

some other kind of knowledge, the kind that, as Flaubert would have said, goes into 'the soul' of a historical situation, that grasps its human content. Perhaps a novel, a great novel, could have made me understand how the Czechs of that time had experienced their decision. Well, such a novel has not been written. There are cases where nothing can make up for the absence of a great novel. 
Here we find all the hallmarks of modernity that lead to widespread protofictional discourse: the unfolding of incomprehensible real-world events; a sense of bewilderment and powerlessness; subjective uncertainty; a plea for humanity in the face of bureaucracy; and an ultimate recourse to fictional devices. Paradoxically, we search for stories in order to make sense of reality. In an article for New Scientist, Helen Phillips suggests that this propensity for storytelling may be hardwired into the human mind. When the parts of the brain that deal with perception, memories and desire disengage (most frequently in older people and trauma victims), a process that has tellingly been named 'confabulation' often occurs, whereby the mind will construct outlandish fictional accounts of the world in order to cope with events it cannot comprehend. These are not exactly lies, as sufferers are demonstrably convinced by their own tall tales, and most studies have centred on the most elaborate of these. However, recent research suggests that confabulation is not just the result of faulty connections; it is in fact deeply rooted in everyday behaviour. Phillips quotes neuroscientist Morten Kringelbach, who suggests that,

even when confronted with seemingly insignificant decisions, 'we simply do not have access to all of the unconscious information on which we base our decisions, so we create fictions upon which to rationalise them [...] If we were aware of how we made every choice we would never get anything done-we cannot hold that much information in our consciousness.

When we experience an unsettling conviction that, in a phrase that resurfaces everywhere from conspiracy theory, to religious belief, to economics, to postmodernism, 'everything is connected', we rationalise the excess by confabulating our own protofictional dérive through truth and the imagination in pursuit of meaning. Just as the peripheries of literature may breed the most radical renovations of the novel, the oft-dismissed corners of networked modernity may be those that reveal the extent to which life aspires to the condition of fiction.

Birkbeck College, University of London 